\title{
Shari'a AND Human Rights, The Challenges Ahead
}

\author{
Abdulkadir Mubarak \\ Department of Private and Islamic Law, Faculty of Law, \\ University of Abuja, Nigeria
}

There are some people among the non-Muslims and even the Muslims who spread confusion that the concept of human rights is alien to Shari'a (Islamic law) and it has no place in the provisions of the Holy Qur'an (the main source of the Shari'a).

The critics of Shari'a have used Universal Declaration of Human Rights (UDHR) as the standard through which Shari'a is evaluated and faulted.

The basic concept of Shari'a in regard to the human rights is based upon equality, dignity and respect for humankind. As is clear from verses of the Holy Qur'an, Allah Almighty has endowed on human beings the status of being superior to all other creations. The Holy Qur'an has described the position enjoyed by human beings in great detail that at the time of creation of Adam, Allah Almighty enjoined upon the angels to bow before Adam.

It was for the first time in the history of mankind that Islam did away with all biases and discriminations on the basis of wealth, clan and tribe, language, sex, colour and caste etc. It termed all human beings equal in status whether one is poor or rich, black or white, woman or man or whether one belongs to this or that region or race.

Keywords: Shari'a, human rights, freedom, apostasy, justice, Western concept, non-Muslims

\section{Introduction}

The recent events occurring in some Muslim countries of the Middle East and North Africa which caused the change of governments in Tunisia, Egypt and Libya and paved the way for the civil war prevailing nowadays in

Corresponding author: aamubarak@hotmail.com 
Syria, more especially after the victory of Islamic activists in Egypt and Tunisia, makes critics of Sharia in the Western world and their counterparts in the Islamic world embark upon creating differences and sectarian clashes between Muslim Sunni and Shi'a on the one hand and between Muslims and followers of other religions on the other, aiming at spreading confusion and misunderstanding about the teachings of Islam and its stand on human rights. In view of these circumstances, it is all the more necessary to bring the Islamic teachings in correct perspective to serve the cause of co-existence Islam so emphatically lays its stress on.

The confusion being spread is because some provisions of the Shari'a are not well understood and/or are deliberately misquoted by non-Muslim or even by Muslim liberals or because of certain events that have taken place within some Muslim countries' borders. This is why they keep on saying that the concept of human rights is alien to Shari'a (Islamic law) and it has no place in the provisions of the Holy Qur'an (the main source of the Shari'a).

Some would maintain that Islamic culture is itself a stumbling block to human rights and freedom. To maintain such a position is to misunderstand not only the religion of Islam, but society, history and the culture of those who first embraced Islam and benefited from its social, economic, cultural and moral reforms.

In this paper I shall examine verses of the Holy Qur'an and other sources to prove that Islam not only defends human rights but even has provided worldly punishment and eternal torment for those who do away with other peoples' right regardless of their culture, creed, history, colour, sex, etc.

I therefore conclude by showing that the concept of human rights echoed and advocated by the Sharia (Islamic law) is unique in its aim and is more perfect than the western concept of human rights in protecting and upholding human dignity.

\section{Western perception of human rights}

Human rights are rights inherent to all human beings, regardless of our nationality, place of residence, sex, national or ethnic origin, colour, religion, language, or any other status. We are all equally entitled to our human rights without discrimination. These rights are all interrelated, interdependent and indivisible (United Nations, What are Human Rights?).

Universal human rights are often expressed and guaranteed by law, in the forms of treaties, customary international law, general principles and other sources of international law. International human rights law lays down obligations of Governments to act in certain ways or to refrain from certain 
acts, in order to promote and protect human rights and fundamental freedoms of individuals or groups (ibid.).

\section{The Emergence of Human Rights in the West}

The concept of human rights in the Western world in its present shape is not an old phenomenon. It dates back only to $16^{\text {th }}$ and $17^{\text {th }}$ centuries when political thinkers and legal experts presented the concepts of basic rights and civil freedoms (Tahir-ul-Qadri, Islamic Concept of Human Rights).

The thoughts of those thinkers and philosophers in the West created an unending conflict between the rulers and the ruled that led to struggles and clashes between imperialist forces and common people for achieving these freedoms and rights. A great progress was made in the realm of human rights when people of Great Britain got their rights through a series of legal documents namely Magna Carta (1215), Petition of Rights (1628) and Bill of Rights (1689) (ibid.). The people of France won their freedoms through Declaration of Rights after the French Revolution in 1789 (ibid.). The USA got its freedom through the War of Independence in 1776. Its people achieved basic rights in 1791 in the form of Bill of Rights, which laid the foundation of first ten amendments in the American constitution (ibid.). The modern nation-states have made the basic human rights the part of their respective constitutions under the influence of various UN conventions and Declarations.

\section{Definition of Sharia (Islamic Law)}

Shari'a literally means a water hole where animals gather daily to drink, or the straight path as in the Qur'an verse.

"Then we put you on a straight path (Sharia) in your affairs, so follow it and do not follow the desires of those who have no knowledge."

Islamically, however, it refers to the sum total of Islamic laws which were revealed to the Prophet Muhammad. It is the body of revealed laws found both in the Qur'an and in the Sunnah.

\subsection{Sources of Shari'a (Islamic Law)}

Before addressing the issue of human rights in Islam, it is useful to clarify that the Shari'a (Islamic Law) like other major religious traditions - does not consist of, or derive from, a single source. If asked about its sources, most Muslims are likely to refer to more than one of the following: the Qur'an or 
the Book of Revelation which Muslims believe to be God's Word transmitted through the agency of Angel Gabriel to the Prophet Muhammad; Sunnah or the practical traditions of the Prophet Muhammad and the twelve Imams from his progeny; Hadith or the oral sayings attributed to the Prophet $\mathrm{Mu}$ hammad and also to the twelve Imams from his progeny; Ijmaa' (Concensus) and Qiyas or Aql (Intellect). The Shari'a or the code of law regulates the diverse aspects of a Muslim's life.

These "sources" are not identical or considered to be of equal weight. Of all the sources of the Islamic Law, undoubtedly, the most important is the Qur'an, which is regarded by Muslims in general, as the primary, and most authoritative, source of normative Islam.

\section{The Holy Qur'an}

The Qur'an is the first and most important source of Sharia. Believed to be the direct word of God as revealed to Prophet Muhammad through Angel Gabriel in Mecca and Medina, the scripture specifies the moral, philosophical, social, political and economic basis on which a society should be constructed.

To many Muslims the Qur'an is the origin of human rights and a large part of its concern is to free human beings from the bondage of traditionalism, authoritarianism (religious, political, economic, or any other), tribalism, racism, sexism, slavery or anything else that prohibits or inhibits human beings from actualizing the Qur'an's vision of human destiny embodied in the proclamation: “Towards Allah is thy limit" (The Holy Qur'an 53:42).

In the Holy Qur'an there is an affirmation of fundamental rights which all human beings ought to possess because they are so deeply rooted in our humanness that their denial or violation is tantamount to a negation or degradation of that which makes us human. From the perspective of the Qur'an, these rights came into existence when we did; they were created, as we were, by God in order that our human potential could be actualized. Rights created or given by God cannot be abolished by any temporal ruler or human agency. Eternal and immutable, they ought to be exercised since everything that God does is for "a just purpose" (The Holy Qur'an 17:70).

\section{Shari'a as a Way of Life for Muslims}

Shari'a is not just a set of ritual codes. It is both a religion and a perfect way of life. For a non-Muslim, religion may be a private relationship between man and his creator. But for a Muslim religion comprehends the whole of life. No sphere is left in which the thoughts and deeds of a Muslim - both in 
his personal and public life - are inconsequential to his fate in the hereafter. This is why Islam does not make a distinction between what is religious and what is secular, nor does it recognise division of authority between Allah and Caesar.

In Islam, only Allah is the Law-giver, because He is the Creator. Allah therefore owns everything. Caesar, a creature of Allah, has nothing, except what has been entrusted to him by his Creator. Thus, all aspects of life - religious, educational, social, political, economic and legal have their legitimate place in the all-inclusive system of Islam. This is why Allah calls upon Prophet Muhammad to say:

"Verily, my prayer, my sacrifice, my living and my dying are for Allah, the Lord of the worlds" (The Holy Qur'an 6:162).

This means that the whole life of man in all spheres should be an expression of complete submission to Allah, the Creator of the universe.

\section{Sharia (Islamic Law) and its Modern Critics}

The critics of Sharia have used Universal Declaration of Human Rights (UDHR) as the standard through which Shari'a is evaluated and faulted. Because UDHR is rooted in the political culture of Western society, and is informed by the philosophical outlook of Western liberalism, its application in other societies requires that the universal validity of its principles is made evident to other peoples, particularly those whose worldviews and historical experiences are different from the West's. Realizing that the claim of universality cannot be established on theoretical grounds, most "international human rights" advocates advance practical and pragmatic reasons for establishing universality claims. Some emphasize the fact that peoples of different cultural and geographical backgrounds "share a common humanity, which means that they equally deserve rights and freedom" (Mayer 1995: 7). Others point out that the UDHR has been framed by representatives of the various nations that constitute the United Nations (UN), and hence conclude that UDHR receives the support of various cultures and religious communities. Still others argue that human rights were developed in modern times to protect individuals from the encroachment of the modern nation-state. Because the nation-state is the basic political organization for all societies and cultures, the need for adopting international human right to protect individual liberties is universal (see: Afshari 1994: 235-276).

Several major, predominantly Muslim, countries criticized the Universal Declaration of Human Rights (UDHR) for its perceived failure to take into 
account the cultural and religious context of non-Western countries. Iran claimed that the UDHR was "a secular understanding of the Judeo-Christian tradition", which could not be implemented by Muslims without trespassing the Islamic law.

In 1990 the Organization of Islamic Conference (OIC), a group representing all Muslim majority nations, adopted the Cairo Declaration on Human Rights in Islam (CDHRI). Ann Elizabeth Mayer, points to notable absences from the Cairo Declaration: provisions for democratic principles, protection for religious freedom, freedom of association and freedom of the press, as well as equality in rights and equal protection under the law. Mayer contends that contemporary endorsement of international human rights by Muslims is more apparent than real, because all human rights pronouncements by Muslim individuals and groups have been curtailed by qualifications rooted in Shari'a (Mayer 1995: 64-65). The application of Sharia law would lead, she concludes, to serious breaches of international human rights. More specifically, the application of Shari'a law would lead to the erosion of religious freedom and to discrimination against women and non-Muslims. Article 24 of the Cairo Declaration states that "all the rights and freedoms stipulated in this Declaration are subject to the Islamic Shari'a" (ibid.: 89).

\section{Islamic Concept of Human Rights}

Since God is the absolute and the sole master of men and the universe, $\mathrm{He}$ is the sovereign Lord, the Sustainer and Nourisher, the Merciful, Whose mercy enshrines all beings; and since He has given each man human dignity and honour, and breathed into him of His own spirit, it follows that, united in Him and through Him, and apart from their other human attributes, men are substantially the same and no tangible and actual distinction can be made among them, on account of their accidental differences such as nationality, colour or race. Every human being is thereby related to all others and all become one community of brotherhood in their honourable and pleasant servitude to the most compassionate Lord of the Universe. In such a heavenly atmosphere the Islamic confession of the oneness of God stands dominant and central, and necessarily entails the concept of the oneness of humanity and the brotherhood of mankind.

Although an Islamic state may be set up in any part of the earth, Islam does not seek to restrict human rights or privileges to the geographical limits of its own state. Islam has laid down some universal fundamental rights for humanity as a whole, which are to be observed and respected under all circumstances whether such a person is resident within the territory of the Islamic state or outside it, whether he is at peace or at war. The Qur'an very clearly states: 
"O believers, be you securers of justice, witness for God. Let not detestation for a people move you not to be equitable; be equitable - that is nearer to God-fearing" (The Holy Qur'an 5:8).

Human blood is sacred in any case and cannot be spilled without justification. And if anyone violates this sanctity of human blood by killing a soul without justification, the Quran equates it to the killing of entire mankind.

“...Whoso slays a soul not to retaliate for a soul slain, nor for corruption done in the land, should be as if he had slain mankind altogether" (The Holy Qur'an 5:32).

It is not permissible to oppress women, children, old people, the sick or the wounded. Women's honour and chastity are to be respected under all circumstances. The hungry person must be fed, the naked clothed and the wounded or diseased treated medically irrespective of whether they belong to the Islamic community or are from among its enemies.

When we speak of human rights in Islam we really mean that these rights have been granted by God; they have not been granted by any king or by any legislative assembly. The rights granted by the kings or the legislative assemblies, can also be withdrawn in the same manner in which they are conferred. The same is the case with the rights accepted and recognized by the dictators. They can confer them when they please and withdraw them when they wish; and they can openly violate them when they like. But since in Islam human rights have been conferred by God, no legislative assembly in the world or any government on earth has the right or authority to make any amendment or change in the rights conferred by God. No one has the right to abrogate them or withdraw them; nor are they basic human rights those which are conferred on paper for the sake of show and exhibition and denied in actual life when the show is over. Nor are they like philosophical concepts which have no sanctions behind them.

It is to be understood very clearly that the basic concept of Islam in regard to the human rights is based upon equality, dignity and respect for humankind. As is clear from the Holy Qur'an, Allah Almighty has endowed on human beings the status of being superior to all other creations. The Holy Qur'an has described the position enjoyed by human beings in great detail that at the time of creation of Adam, Allah Almighty enjoined upon the angels to bow before Adam.

It was for the first time in the history of mankind that Islam did away with all biases and discriminations on the basis of wealth, clan and tribe, language, sex, colour and caste etc. It termed all human beings equal in status whether one is poor or rich, black or white, woman or man or whether one belongs to this or 
that region or race. What greater example of human equality can there be than that in which people belonging to various countries, languages and races gather at the precincts of the Holy Ka'aba for worship and wear the same dress.

After laying the foundation of respect and equality of man, Islam prescribed a complete charter of rights for humanity ranging from moral rights to religious, economic, social and political rights. Islamic concept of human rights and freedoms is uniform and of universal character, which is independent of historical and regional boundaries of time and space.

\section{Islamic and Western Concept of Human Rights Compared}

The Islamic concept of human rights originates from the commandments of Allah Almighty, which were conveyed to people through the Holy Prophet.

The rights given by Allah are in the form of blessings and there is no role of any human effort in their acquirement. Contrary to the Western version of rights which are violable in nature, given by the earthly law-makers, the rights given by Allah are permanent, unchangeable, inviolable and sacred. Since Divine intent underlines them, they cannot be suspended, amended or changed. In a real Islamic state, these rights are to be enjoyed by every citizen. Neither can any state nor an individual violate them.

Another unique feature of Islamic concept is that here rights and duties are interdependent and complement each other. That is why obligations and duties have equally been stressed upon as rights.

It is regrettable that while terming West torch-bearer of human rights, the contribution of Islam in ordaining these rights is ignored.

Islam teaches moderation and balance in life. The teachings of the Holy Prophet provide a guarantee to create balance in life. This basic principle of Islam characterizes all of its teachings and commandments. The human rights granted by Islam bear the same stamp. No other social and political system can match that of Islam in its practicality, moral outlook and result-orientedness. The Islamic concept of rights is different from the philosophies of other systems in the following ways:

Islam preaches fulfilment of rights rather than demand of rights. The basic teaching of Islam is that every person is under obligation to realize the rights of others in every possible way. The society will become an ideal society where duty of one individual is the right of other. When people are engaged in the fulfilment of their rights with this consciousness, such societies become the paragon of respect for rule of law and human rights.

The Holy Prophet has presented such a system of human rights, which has reciprocal relationship and proportionality between rights and duties. 
That means that no person will be justified in demanding their rights unless they perform their (own) obligations. Since the main stress is laid on the performance of duties, no individual can raise his voice for rights as long as they do not perform their (own) duties. Thus the rights stand fulfilled automatically in the process of performance of duties.

The Islamic concept of human rights is comprehensive and compact in that it has proportion and balance between rights and duties. The lack of understanding of this basic concept has given rise to many confusions and misunderstandings.

Islam has termed some matters to be duties not rights keeping in view their legal and social importance whose non-performance has been held as punishable act. For example bearing witness is obligatory on males. The transparent and effective system of evidence is a necessary element for the establishment of the rule of law in society.

That is why our religion has held men responsible for bearing witness, while the women have been absolved of this responsibility owing to their natural biological difference. Now it is their right not duty.

There is no doubt about the fact that Islam and the West attach great importance to basic freedoms and human rights but their perspectives are basically different on the issue of human rights. The difference is explained in terms of their basic varying outlooks. Islam looks at human rights in the perspective of man's total obedience to Allah Almighty whereas the Western concept of human rights is totally secular, and is based on man's relations with the state as a citizen.

If analysed broadly, the real difference is that in Islam, source of all powers is Allah Almighty, Who is the founder of all worlds. His commandments are the supreme law. Man is vicegerent of Allah on this earth. People are not repository of absolute powers. Rather they exercise these powers through their elected representatives within the limits set by Allah. The exercise of these powers is regarded as trust. Contrary to this, people are considered as a source of all powers in secular, democratic societies of the West. The constitutions so framed by the representatives of people are accepted as supreme law of the land.

It is on the basis of this difference on the source of absolute powers that there are different perspectives of Islam and the West on human rights. Islam makes a clear and comprehensive statement of civil freedoms and rights, which are inviolable and sacred. However law-making institutions of the Islamic state enjoy the rights of making amendments in these rights keeping in view the demands of the changing social, political and economic circumstances provided these modifications are in consonance with the spirit of the Holy Qur'an, Sunnah and the Islamic law. Another important feature of these rights is that they have universal character and can be enjoyed both by Muslim and non-Muslim citizens. 
On the other hand, people in the West have been able to achieve these rights after undertaking great protracted struggles. Moreover their successes on this front are a recent phenomenon and stand the chance of being reversed on this or that reason. In the third world countries, these rights do not enjoy any respect as they are only found in the statute books and not implemented. Here, in these modern democratic countries, the scope of basic rights is limited, not universal. The Vienna Declaration adopted at the International Conference on Human Rights in June 1993 stated:

"All human rights are universal, indivisible and interdependent and interrelated."

In spite of adopting this concept of human rights constitutionally, Article 10 of Human Rights Charter (2000) of European Union stated:

"Certain rights shall be reserved for citizens of the European Union."

The point being contended here is that certain rights are reserved for its citizens in the West, which can be enjoyed neither by expatriates nor minorities. Various Declarations and Conventions adopted by the United Nations are no doubt universal but their implementation is not bound by any legal sanction.

The charter and the proclamations and the resolutions of the United Nations cannot be compared with the rights sanctioned by God; because the former are not applicable on anybody while the latter are applicable on every believer. They are part and parcel of the Islamic Faith. Every Muslim or administrator who claims to be Muslim will have to accept, recognize and enforce them. If they fail to enforce them, and start denying the rights that have been guaranteed by God or make amendments and changes in them, or practically violate them while paying lip service to them, the verdict of the Holy Qur'an for such government is clear and unequivocal:

"Those who do not judge by what God has sent down are the disbelievers" (The Holy Qur'an 5:44).

\section{The General Rights Echoed by Sharia (the Islamic Law)}

While in International documents the principle of universality of human rights is the cornerstone of international human rights law and this principle, as first emphasized in the Universal Declaration on Human 
Rights in 1948, has been reiterated in numerous international human rights conventions, declarations, and resolutions and even the 1993 Vienna World Conference on Human Rights, for example, noted that it is the duty of States to promote and protect all human rights and fundamental freedoms, regardless of their political, economic and cultural systems. Islam has laid down principles on general rights. Islam gives the right of freedom of thought and expression to all citizens of the Islamic state on condition that it should be used for the propagation of virtue and truth and not for spreading evil and wickedness. The Islamic concept of freedom of expression is much superior to the concept prevalent in the West. Under no circumstances would Islam allow evil and wickedness to be propagated.

Here, an account is given of the Qur'an's affirmation of some fundamental rights which all human beings ought to possess because they are so deeply rooted in our humanness that their denial or violation is tantamount to a negation or degradation of that which makes us human.

\section{Right to Life}

The Qur'an upholds the sanctity and absolute value of human life (The Holy Qur'an 6:151) and points out that, in essence, the life of each individual is comparable to that of an entire community and, therefore, should be treated with utmost care (Qur'an 5:32).

\section{Right to "The Good Life"}

The Holy Qur'an upholds the right of the human being only to life but to "the good life". This good life, made up of many elements, becomes possible when a human being is living in a just environment. According to Qur'an's teaching, justice is a prerequisite for peace, and peace is a prerequisite for human development. In a just society, all the earlier-mentioned human rights may be exercised without difficulty. In such a society other basic rights such as the right to a secure place of residence, the right to the protection of one's personal possessions, the right to protection of one's covenants, the right to move freely, the right to social and judicial autonomy for minorities, the right to the protection of one's holy places and the right to return to one's spiritual centre, also exist. ${ }^{1}$

1 In this context, reference may be made to several Qur'anic verses. e.g., Surah 2:Al-Baqarah:229; Surah 3: Al-'Imran: 17,77; Surah 5: Al-Ma'idah:1; 42-48; Surah 9: At-Tawbah: 17; Surah 17: Al-Isra': 34; Surah 67: Al-Mulk:15. 


\section{Right to Basic Necessities of Life}

Islam has recognized the right of the needy people for help and assistance to be provided to them:

"And in their wealth there is acknowledged right for the needy and the destitute" (The Holy Qur'an 51:19).

\section{Right to Respect}

The Holy Qur'an deems all human beings to be worthy of respect (Qur'an 17:70) because of all creation they alone chose to accept the "trust" of freedom of the will (Qur'an 33:72). Human beings can exercise freedom of the will because they possess the rational faculty, which is what distinguishes them from all other creatures (Qur'an 2:30-34). Though human beings can become "the lowest of the lowest", the Qur'an declares that they have been made "in the best of moulds" (Qur'an 95:4-6), having the ability to think, to have knowledge of right and wrong, to do the good and to avoid the evil. Thus, on account of the promise which is contained in being human, namely, the potential to be God's vicegerent on earth, the humanness of all human beings is to be respected and considered to be an end in itself.

\section{Right to Justice}

The Qur'an puts great emphasis on the right to seek justice and the duty to do justice (Qur'an 5:8, 4:136). In the context of justice, the Qur'an uses two concepts: "adl" and "ihsan". Both are enjoined and both are related to the idea of "balance", but they are not identical in meaning.

Justice introduces the balance in the form of scales that are evenly balanced (Fyzee 1978: 17). "Adl” was described in similar terms by Abul Kalam Azad, a famous translator of the Qur'an and a noted writer, who stated: "What is justice but the avoiding of excess? There should be neither too much nor too little; hence the use of scales as the emblems of justice" (ibid.). Lest anyone try to do too much or too little, the Qur'an points out that no human being can carry another one's burden or attain anything without striving for it (Qur'an 53:38-39).

Recognizing individual merit is a part of "adl", the Qur'an teaches that merit is not determined by lineage, sex, wealth, worldly success or religion, but by righteousness, which consists of both right "belief" ("iman") and just action" (“amal”) (Qur'an 2:177). Further, the Qur'an distinguishes between 
passive believers and those who strive in the cause of God pointing out that though all believers are promised good by God, the latter will be exalted above the former (Qur'an 4:95-96).

Just as it is in the spirit of "adl" that special merit is considered in the matter of rewards, so are special circumstances to be considered in the matter of punishments. For instance, for crimes of unchastity the Qur'an prescribes identical punishments for a man or a woman who is proved guilty (Qur'an 24:2), but it differentiates between different classes of women: for the same crime, a slave woman would receive half, and the Prophet's consort double, the punishment given to a "free" Muslim woman (Qur'an 4:25, 33:30). In making such a distinction, while upholding high moral standards, particularly in the case of the Prophet's wives whose actions have a normative significance for the community, the Qur'an reflects God's compassion for women slaves who were socially disadvantaged.

While constantly enjoining "adl", the Qur'an goes beyond this concept to "ihsan", which literally means "restoring the balance by making up for a loss or deficiency" (Parwez 1977: 78). In order to understand this concept, it is necessary to understand the nature of the ideal society or community ("ummah") envisaged by the Qur'an. The word "ummah" comes from the root "umm", or "mother". The symbols of a mother and motherly love and compassion are also linked with the two attributes most characteristic of God, namely, "Rahim" and "Rahman", both of which are derived from the root "rahm", meaning "womb". The ideal "ummah" cares about all its members just as an ideal mother cares about all her children, knowing that all are not equal and that each has different needs. While showing undue favour to any child would be unjust, a mother who gives to a "handicapped" child more than she does to her other child or children is not acting unjustly but exemplifying the spirit of "ihsan" by helping to make up for the deficiency of a child who needs special assistance in meeting the requirements of life. "Ihsan", thus, shows God's sympathy for the disadvantaged segments of human society (such as women, orphans, slaves, the poor, the infirm, and the minorities).

\section{Right to Freedom}

The Qur'an is deeply concerned about liberating human beings from every kind of bondage. Recognizing the human tendency toward dictatorship and despotism, the Qur'an says with clarity and emphasis in chapter 3, verse 79:

"It is not (possible) That a man, to whom Is given the Book, and Wisdom, And the Prophetic Office, Should say to people: 'Be ye my worshippers 
Rather than Allah's' On the contrary (He would say): 'Be ye worshippers Of Him Who is truly The Cherisher of all”' (Yusuf Ali 1989: 148).

The institution of human slavery is, of course, extremely important in the context of human freedom. Slavery was widely prevalent in Arabia at the time of the advent of Islam, and the Arab economy was based on it. Not only did the Qur'an insist that slaves be treated in a just and humane way (Qur'an 4:36), but it continually urged the freeing of slaves (Qur'an 2:177, 4:92, 5:89, 9:60, 24:33, 58:3). By laying down, in chapter 47: verse 4 , that prisoners of war were to be set free, "either by an act of grace or against ransom" (Asad 1980: 778), the Qur'an virtually abolished slavery since "The major source of slaves - men and women - was prisoners of war" (Parwez 1986: 346). Because the Qur'an does not explicitly state that slavery is abolished, it does not follow that it is to be continued, particularly in view of the numerous ways in which the Qur'an seeks to eliminate this absolute evil. A Book which does not give a king or a prophet the right to command absolute obedience from another human being could not possibly sanction slavery in any sense of the word.

The greatest guarantee of personal freedom for a Muslim lies in the Qur'anic decree that no one other than God can limit human freedom (Qur'an 42:21) and in the statement that "Judgment (as to what is right and what is wrong) rests with God alone" (Qur'an 12:40).

The Qur'an recognizes the right to religious freedom not only in the case of other believers in God, but also in the case of non-believers (if they are not aggressing upon Muslims) (Qur'an 6:108).

In the context of the human right to exercise religious freedom, it is important to mention that the Qur'anic dictum, "Let there be no compulsion in religion" (Qur'an 2:256) applies not only to non- Muslims but also to Muslims. While those who renounced Islam after professing it and then engaged in "acts of war" against Muslims were to be treated as enemies and aggressors, the Qur'an does not prescribe any punishment for non-profession or renunciation of faith. The decision regarding a person's ultimate destiny in the hereafter rests with God.

The right to freedom includes the right to be free to tell the truth. The Qur'anic term for truth is "Haqq" which is also one of God's most important attributes. Standing up for the truth is a right and a responsibility which a Muslim may not disclaim even in the face of the greatest danger or difficulty (Qur'an 4:135). While the Qur'an commands believers to testify to the truth, it also instructs society not to harm persons so testifying (see: Qur'an 2, Parwez 1981: 34-35).

It is to be understood that the basic concept of Islam with regard to human rights is based upon equality, dignity and respect for humankind. 
As clearly mentioned in the Holy Qur'an, Allah Almighty has endowed on human beings the status of being superior to all other creations. Respecting human dignity and employing justice between people in all aspects of life without any discrimination of race, colour, tribe, religion, family background etc. is contained in the provisions of the Holy Qur'an. Therefore by carefully studying the contents of the Holy Qur'an, critics and the so-called human rights activists will realize their mistakes and admit to the fact that the Holy Scripture provides humankind with all the necessary rights it deserves and even better than that contained in the international declaration of human rights.

\section{Right to Acquire Knowledge}

The Holy Qur'an puts the highest emphasis on the importance of acquiring knowledge. That knowledge has been at the core of the Islamic worldview from the very beginning is attested to by Surah 96: Al-'Alaq: $1-5$, which Muslims believe to be the first revelation received by the Prophet Muhammad.

Asking rhetorically if those without knowledge can be equal to those with knowledge (Qur'an 39:9), the Qur'an exhorts believers to pray for advancement in knowledge (Qur'an 20:114). The famous prayer of the Prophet Muhammad was "Allah, grant me Knowledge of the ultimate nature of things" and one of the best known of all traditions ("ahadith") is "Seek knowledge even if it be in China."

According to Qur'anic perspective, knowledge is a prerequisite for the creation of a just world in which authentic peace can prevail. The Qur'an emphasizes the importance of the pursuit of learning even at the time, and in the midst, of war (Qur'an 9:122).

\section{Right to Sustenance}

As pointed out by Holy Qur'an (11:6), every living creature depends for its sustenance upon God. A cardinal concept in the Qur'an - which underlies the socio-economic-political system of Islam - is that the ownership of everything belongs, not to any person, but to God. Since God is the universal creator, every creature has the right to partake of what belongs to God (Qur'an 6:165, 67:15). This means that every human being has the right to a means of living and that those who hold economic or political power do not have the right to deprive others of the basic necessities of life by misappropriating or misusing resources which have been created by God for the benefit of humanity in general. 


\section{Right to Work}

According to Qur'anic teaching every man and woman has the right to work, whether the work consists of gainful employment or voluntary service. The fruits of labour belong to the one who has worked for them - regardless of whether it is a man or a woman. As the Holy Qur'an states: ...to men is allotted what they earn, and to women what they earn (Qur'an 4:32).

\section{Right to Privacy}

The Holy Qur'an recognizes the need for privacy as a human right and lays down rules for protecting an individual's life in the home from undue intrusion from within or without (Qur'an 27:27-28, 58, 33:53, 49:12).

\section{Right to Protection from Slander, Backbiting, and Ridicule}

The Holy Qur'an recognizes the right of human beings to be protected from defamation, sarcasm, offensive nicknames, and backbiting (Qur'an 49:11-12). It also states that no person is to be maligned on grounds of assumed guilt and that those who engage in malicious scandal-mongering will be grievously punished in both this world and the next (Qur'an 24:16-19, 4:148-149).

\section{Right to Develop One's Aesthetic Sensibilities and Enjoy the Bounties Created by God}

By declaring that all good and beautiful things belong to the believers, the Holy Qu'ran condemns, by implication, all forms of life-denying asceticism, world - renunciation and self-mortification (Asad 1980: 207). In fact, it can be stated that the right to develop one's aesthetic sensibilities so that one can appreciate beauty in all its forms, and the right to enjoy what God has provided for the nurture of humankind, are rooted in the life-affirming vision of the Holy Qur'an (7:32).

\section{Right to Leave One's Homeland under Oppressive Conditions}

According to Qur'anic teaching, a Muslim's ultimate loyalty must be to God and not to any territory. To fulfil his Prophetic mission, the Prophet 
Muhammad decided to leave his place of birth, Mecca, and immigrated to Medina. This event ("Hijrah") has great historical and spiritual significance for Muslims who are called upon to move away from their place of origin if it becomes an abode of evil and oppression where they cannot fulfil their obligations to God or establish justice (Qur'an 4:97-100).

\section{The Protection of Honour}

The Holy Qur'an lays down the following:

"You, who believe, do not let one (set of) people make fun of another set."

"Do not defame one another."

"Do not insult by using nicknames."

"Do not backbite or speak ill of one another" (Qur'an 49:11-12).

\section{Sanctity and Security of Private Life}

The Qur'an laid down the injunction:

"Do not spy on one another" (Qur'an 49:12).

"Do not enter any houses unless you are sure of their occupant's consent" (Qur'an 24:27).

\section{The Right to Protest against Tyranny}

Among the rights that Islam has conferred on human beings is the right to protest against government's tyranny. Referring to it the Qur'an says:

"God does not love evil talk in public unless it is by someone who has been injured thereby" (Qur'an 4:148).

In Islam, as has been argued earlier, all power and authority belong to God, and with man there is only delegated power which becomes a trust; everyone who becomes a recipient of such power has to stand in awful reverence before his people toward whom and for whose sake he will be called upon to use these powers. This was acknowledged by Abu Bakr ibn Abi Quhafa (the first caliph), who said in his very first address: "Cooperate with me when I am right but correct me when I commit error; obey me so long as I follow the commandments of Allah and His Prophet; but turn away from me when I deviate." 


\section{Freedom of Expression}

Islam gives the right of freedom of thought and expression to all citizens of the Islamic state on the condition that it should be used for the propagation of virtue and truth and not for spreading evil and wickedness. The Islamic concept of freedom of expression is much superior to the concept prevalent in the West. Under no circumstances would Islam allow evil and wickedness to be propagated. It also does not give anybody the right to use abusive or offensive language in the name of criticism. It was the practice of the Muslims to enquire from the Holy Prophet whether on a certain matter a divine injunction had been revealed to him. If he said that he had received no divine injunction, the Muslims freely expressed their opinion on the matter.

\section{Protection from Arbitrary Imprisonment}

Islam also recognizes the right of the individual not to be arrested or imprisoned for the offenses of others. The Holy Qur'an laid down this principle clearly:

"No bearer of burdens shall be made to bear the burden of another" (Qur'an 35:18).

\section{The Right to Participate in the Affairs of State}

"And their business is (conducted) through consultation among themselves" (Qur'an 42:38).

The "Shura" or the legislative assembly has no other meaning except that the executive head of the government and the members of the assembly should be elected by free and independent choice of the people.

\section{Freedom of Conscience and Conviction}

There is ample evidence in the verses of the Holy Qur'an, both the Meccan and Medinan, that individuals should be able to accept or reject a particular faith on the basis of personal conviction, and that no amount of external pressure or compulsion should be permitted:

"No compulsion in religion: truth stands out clear from error" (Qur'an 2:256). 
"If it had been the Lord's will, they would have believed - All who are on earth! Will you then compel mankind, against their will, to believe!" (Qur'an 10:99).

By emphasizing people's right to freely follow their conviction, the Qur'an reiterates a long standing position, which it traces back to one of the earliest known Prophets, Noah ${ }^{1}$. Not only does the Qur'an recognize the individual's right to freedom of conviction, but it also recognizes their moral freedom to act on the basis of their conviction. ${ }^{2}$ The principle that the larger community has no right to interfere in one's choices of faith and conviction can be seen, further, in the fact that the Qur'an emphasizes that the individual is accountable for the moral choices he or she makes in this life to their Creator alone. ${ }^{3}$

Yet despite the Qur'anic emphasis on the freedom of conviction and moral autonomy, most classical jurists contend that a person who renounces Islam or converts to another religion commits a crime of ridda (apostasy) punishable by death.

1 "He [Noah] said: O my people! See if I have a clear sign from my Lord, and that he has sent mercy unto me, but that the mercy has been obscured from your sight? Shall we compel you to accept it when you are averse to it!" (chapter 11: verse 28). "The message of freedom of belief and conviction, and the call to religious tolerance is reiterated time and again through various Prophets. And if there is a party among you that believes in the message with which I have been sent, and a party which does not believe, hold yourselves in patience until Allah does decide between us: for He is the best to decide. The leaders, the arrogant party among his people, said: O Shu'ayb! We shall certainly drive you out of our city, and those who believe with you, or else you shall have to return to our ways and religion. He said: "What! Even though we do not wish to do so." (chapter 7: verse 86-87).

2 "Say: O my people! Do whatever you may: I will do (my part). But soon will you know on whom an anguish of ignoring shall be visited, and on whom descends an anguish that abide". (chapter 39: verse 39-40). "Say: Everyone acts according to his own disposition: But your Lord knows best who it is that is best guided on the way." (chapter 17: verse 84).

3 "O you, who believe! Guard your own souls: If you follow (right) guidance, no hurt can come to you from those who stray. The goal of you all is God: It is He that will show you the truth of all that you do." (chapter 5: verse 105). "So if they dispute with you, say: I have submitted my whole self to God and so have those who follow me. And say to the People of the Book and to those who are unlearned: Do you (also) submit yourselves? If they do, they are in right guidance. But if they turn back, your duty is to convey the Message; and in God's sight are (all) His servants." (chapter 3: verse 20) In fact, one cannot find in the Qur'an any support for the ridda penalty. The Qur'an makes two references to ridda: "Nor will they cease fighting you until they turn you back from your faith if they can. And if any of you turn back (commit ridda) from their faith and die in unbelief, their works will bear no fruit in this life; and in the hereafter they will be companions of the fire and will abide therein." (chapter 2: verse 217). 


\section{Traditional Treatment of Apostates according to Sharia Law}

Islam teaches that a newborn has an innate ability to know and believe in his creator, and to understand good and evil. Prophet Muhammad stated: "Every child is born with the believing nature... it is his parents who make him into a Jew or a Christian". There is to be no force used to convert a non-believer to Islam. The Qur'an prohibits the use of compulsion to force a person or a society to accept Islam, as previously stated above.

However, once a person freely "enters into the fold of Islam, the rules change". The word "Islam" means "submission to the will of God". The Qur'an says that: "No believing man and no believing woman has a choice in their own affairs when Allãh and His Messenger have decided on an issue" (Qur'an 33:36).

On the issue of apostasy, Islam clearly says: "No! You can not become an apostate." Apostasy is viewed as a form of treason.

In many predominately Muslim countries, the punishment for apostasy is death - assuming that the individual: was a Muslim, openly rejects Islam, has made this decision freely and without coercion, is aware of the nature of his/her statements, and is an adult. Then the penalty prescribed by Shari'a (Islamic) law is execution for men and life imprisonment for women. Drunkards and mentally ill persons are excluded from this punishment because they are considered to be not responsible for their statements.

A person born of a Muslim parent who later rejects Islam is called a "Murtad Fitri" (Apostate - natural). This is viewed a treason against God. They are given a second chance. If they repent of their decision, they will be released. A person who converted to Islam and later rejected the religion is a "Murtad Milli" (apostate - from the community.) This is viewed as treason against the community. Male apostates are executed even if they repent. Female apostates are released from imprisonment if they repent.

If either spouse apostatizes from Islam, a divorce is automatic.

If both apostatize they are generally allowed to stay married.

An under-aged male is imprisoned, and only executed if he remains an apostate when he becomes of age. The will of a male apostate is not valid. A female apostate's will remain valid.

In the rare instances when an apostate is executed, it is traditionally done by severing his neck with a sword.

Among Malikites, Shafi'ites, and Hanbalites, adult women receive the same penalty as men: which is execution.

The Shi ite schools of law allow for Islamic law towards apostates to be applied in non-Muslim countries. That is to say they believe in extraterritorial jurisdiction." 
However, since the Qur'an is unequivocal in supporting religious free$\mathrm{dom}^{1}$, classical jurists from the ahlus-sunah, relied in advocating death penalty for ridda (renouncing Islam) on two hadith texts, and the precedent of the Muslims fighting against Arab apostates under the leadership of Abu Bakr, the first Caliph. This evidence is, though, shaky and does not stand under close scrutiny, relied upon by most Muslim scholars. The two hadith texts reported in Sahih Bukhari state "Kill whoever changes his religion", and "Three acts permit the taking of a person's life: a soul for a soul, the adultery of a married man, and renouncing religion while severing ties with the community". The classical jurists from the Shi'ites also relied upon some hadiths (narrations) related to the Imams of Ahlul-bait. The hadith statements from the both sides cannot stand as credible evidence because they contravene much Qur'anic evidence. According to the Maqasid approach, a hadith can limit the application of a general Qur'anic statement, but can never negate it (al-Shatibi 1994: vol. 3: 15-26). Besides, the hadith even contradicts the practices of the Prophet who reportedly pardoned Muslims who committed ridda. One well-known example is that of Abdullah bin Sa'ad who was pardoned after Osman bin Affan pleaded on his behalf. Ibn Hisham narrated in his Sirah that the Prophet pardoned the people of Quraysh after Muslims entered Meccah victorious in the eighth year of the Islamic calendar.

The Prophet excluded few individuals from this general pardon, whom he ordered to be killed if captured, including Abdullah bin Sa'ad. Abdullah was one of the few persons appointed by the Prophet to write the revealed texts. After spending a while with the Muslims in Medina, he renounced Islam and returned to the religion of Quraysh. He was brought to the court of the Prophet by Osman, who appealed the narration indicates, in a state

1 In fact, one cannot find in the Qur'an any support for the ridda penalty. The Qur'an makes two references to ridda: "Nor will they cease fighting you until they turn you back from your faith if they can. And if any of you turn back (commit ridda) from their faith and die in unbelief, their works will bear no fruit in this life; and in the hereafter they will be companions of the fire and will abide therein." (chapter 2: verse 217) "O you who believe! If any from among you turn back (commits ridda) from his faith, soon will God produce a people whom He will love as they will love Him - humble with the believers mighty against the disbelievers, thriving in the way of God, and never afraid of the reproaches of detractors. That is the grace of God, he bestows on whom He please; and God encompasses all and he knows all things." (chapter 5: verse 54). In both cases the Qur'an does not specify any physical punishment here and now, let alone a death penalty. The Qur'an rather warns those who renounce their faith of disgrace and ill-fate. On the contrary, the Qur'an provides direct evidence, albeit open to interpretation, that ridda is not punishable by death: "Those who believe then disbelieve, then believe again, then disbelieve and then increase in their disbelief - God will never forgive them nor guide them to the path." (chapter 4: verse 137). 
of ridda and was yet to re embrace Islam (Ibn Hisham 1955: vol. 2: 409). If ridda was indeed a hadd, neither Osman would be able to plea for him, nor the Prophet would pardon him in violation of the Shari'a law. That's why the writer inclined to the increasingly popular view among contemporary scholars, that ridda does not involve a moral act of conversion, but a military act of rebellion, whose calming justifies the use of force and the return of fire (see: Kamali 1998: 87-106).

To make things worse, classical jurists extended death penalty to cases of misinterpretation of divine texts, or negligence of religious practices. Thus classical jurists insisted that a Muslim who negates or neglects prayer can be executed if he does not repent within three days. The vast majority of classical jurists maintained that it was not necessary for a Muslim to openly renounce Islam to be subject to death penalty. Rather, it was sufficient for him to say or do something contrary to Islam to be executed. Although jurists called neglecting religious duties or contravening orthodox interpretations zandaqa (heresy) rather than ridda, they treated both as equal in their severity (see: al-Ghazzali 1993: 95-97). Interestingly, heresy punishment is not based on any Qur'anic or Prophetic texts, but on a faulty theory of right.

The widely accepted theory of right among jurists divided rights into three types (see: Sulami 1968: vol 1: 113-121, al-Shatibi 1994: vol. 2: 318320): (1) Rights of God (Huquq Allah) - These consist of all obligations that one has to discharge simply because they are divine commands, even when the human interests or utilities in undertaking them are not apparent, such as prayers, fasting, hajj, etc.; (2) Rights shared by God and his servants (Huquq Allah wa al-'Ibad) - These include acts that are obligatory because they are demanded by God, but they are also intended to protect the public, such as hudud law, jihad, zakat, etc., and (3) Rights of God's servants (Huquq $a l$ - $T$ (bad) - These are rights intended to protect individual interests, such as fulfilling promises, paying back debts, honouring contracts. Still people are accountable for their fulfilment to God.

As it can be seen, the theory of right devised by late classical jurists around the eight Century of Islam - emphasizes that people are ultimately answerable to God in all their dealings. However, by using the term rights of God to underscore the moral duty of the individual, and their accountability before God, classical jurists obscured the fact that rights are invoked to support legal claims and to enforce the interests of the right-holder. Because the Qur'an makes it abundantly clear that obeying the divine revelation does not advance the interests of God, but only those of the human being, the phrase "rights of God" signifies only the moral obligations of the believers towards God, and by no means should they be taken as a justification of 
legal claims. ${ }^{1}$ It follows that the rights of God which are exclusively personal should be considered as moral obligations for which people are only answerable to God in the life to come. As such accepting or rejecting a specific interpretation or a particular religious doctrine, and observing or neglecting fundamental religious practices, including prayer or hajj, should have no legal implications whatever. A legal theory in congruence with the Qur'anic framework should distinguish between moral and legal obligations, and should confine the latter to public law that promote public interests (constitutional, criminal, etc.) and private law that advances private interests (trade, family, personal, etc.).

Unless the above legal reform is undertaken, there is no way to ensure that takfir (charging one with disbelief) and zandaqa (charging one with heresy) claims would not become a political weapon in the hands of political groups to be used as a means to eliminate rivals and opponents. Indeed there is ample evidence to show that zandaqa and takfir have been used by the political authorities during the Umayyad and Abbasid dynasties to persecute political dissidents. ${ }^{2}$

\section{Rights of Non-Muslims}

The record of classical Shari'a concerning the human rights of non-Muslims is mixed. On the one hand the Shari'a recognizes the rights of non-Muslims to enjoy equal protection of the law as far as their life, property, and personal security are concerned. Non-Muslims also enjoyed the rights to freedom of conviction, and the right for self-determination as far as their legal and administrative conditions were involved. On the other hand, classical jurists imposed a number of restrictions on non-Muslims in the area of dress code, display of religious symbols, the construction of churches in predominantly Muslim districts, the use of mounts and carrying of weapons, etc. (see: Ibn Nujaym 1988: 386-388). ${ }^{3}$ It was suggested that the restrictions imposed on non-Muslims do not stem from Qur'anic standards, but rather security concerns during the political turmoil associated with the Mongol and Crusade invasions. Therefore, the apparent indifference on the part of Shari'a towards the civil and political rights of

1 The Qur'an repeatedly points out that people's neglect of its commandments has no consequences onto the Divine whatsoever - be it good or evil — but only onto themselves. See for example: 2 (Baqarah): 57, 7 (al-A'raf): 160, 3 (Ali 'Imran): 176-77, and 47 (Muhammad): 32.

2 The executions of Ghaylan al-Dimashqi by the order of Caliph Abdul Malik bin Marwan, and Ahmed bin Nasir by the order of Caliph al-Wathiq after being accused of heresy are cases in point.

3 Ibn Nujaym belongs to the more tolerant school of Hanafi. 
non-Muslims stems not from any insensitivities attributable to classical jurists, but rather to the literalist approach of contemporary traditionalist jurists. Indeed, the literalist and imitative approach of Islamic traditionalism has been the main obstacle in the way toward evolving a human rights tradition rooted in Islamic sources. The first thing that strikes us when we study the Qur'anic texts is that the Qur'an neither confines faith and salvation to those who accept the Islamic revelation, nor deny faith and salvation to other religions. ${ }^{1}$ Indeed the Qur'an does not limit the attribution of faith and salvation to the People of the Book (Jews and Christians) but extend it to believers of other faiths. ${ }^{2}$ Nor does the Qur'an consider all those who accepted Islam as true believers. For some have accepted the new religion as a general mode of life but failed to internalize its worldview and ethical mission:

"The desert Arabs say, 'We believe.' Say, 'Ye have no faith; but you (only) say, 'we have submitted our wills to God,' for not yet has faith entered your hearts. But if you obey God and His messenger, he will not be little aught of your deeds: for God is oft forgiving, most merciful"' (Qur'an 49:14).

1 "Not all of them are alike! Of the People of the Book are a portion that stand (for the right); they rehearse the signs of God around the night, and they prostrate themselves in adoration. "They believe in God and the Last Day; they enjoin the right and forbid the intolerable (munkar); and they hasten in (all) good works: they are in the rank of the righteous. Of the good that they do, nothing will be rejected of them; for God knows well those that do right." (chapter 3: verse: 113-115) "And there are certainly among the People of the Book those who believe in God, in the revelation to you, and in the revelation to them, bowing in humility to God. They will not sell the signs of God for a miserable gain! For them is a reward with their Lord, and God is swift in account." (chapter 3: Verse: 199).

2 “Those who believe (in the Qur'an), those who follow the Jewish (scriptures), and the Sabians and the Christians - any who believes in God and the Last Day, and work righteousness - on them shall be no fear, nor shall they grieve" (Al-Ma'idah 69). The Qur'an goes even further to make it abundantly clear that no religious community has the right to claim monopoly on righteousness or salvation: "The Jews say: The Christians have naught (to stand) upon; and the Christians say: The Jews have naught (to stand) upon. Yet they (Profess to) study the (same) book. Like unto their work is what those say who know not; but Allah will judge between them in their quarrel on the Day of Judgment." (chapter 2: verse 113) "Indeed the Qur'an rebuke those of the People of the Book who justify the violation of their moral code when dealing with people who belong to another faith: Among the people of the book are some who, if entrusted with a hoard of gold, will (readily) pay it back; others, who, if entrusted with a single silver coin, will not repay it unless you constantly stood demanding, because they say: there is no call on us (to keep faith) with these ignorant (pagans). But they tell a lie against God, and (well) they know it" (chapter 3: verse 75). 
Others conformed to Islamic teachings only in appearance, but continued to harbour suspicion and doubts, even ill-will toward Islam and its adherents and advocates (Qur'an 2:8-20, 4:142). It follows that believers and disbelievers can belong to all religions. Because believers and disbelievers cannot be distinguished on religious lines, as they run across all religions, the Qur'an urges Muslims to seek a political order based on peaceful cooperation and mutual respect, and warns them against placing religious solidarity over covenanted rights and the principles of justice. ${ }^{1}$

Equipped with the above set of principles, the Prophet managed to establish in Medina a multi-religious political community, based on a set of universal principles that constituted the Pact of Medina (Sahifatul Madina) (Ibn Hisham 1955: vol. 1: 17). The various rules enunciated in the Pact were aimed at maintaining peace and cooperation, protecting the life and property of the inhabitants of Medina, fighting aggression and injustice regardless of tribal or religious affiliations, and ensuring freedom of religion and movement. It is remarkable that the Medina Pact placed the rules of justice over and above religious solidarity, and affirmed the right of the victim of aggression and injustice to rectitude regardless of their tribal or religious affiliation, or that of the culprit.

However, it is not sufficient today for Muslim jurists to recognize the moral autonomy of non-Muslim communities, as the classical jurists did. The Qur'anic concept of justice requires that they employ the principle of reciprocity in delineating the overall legal structure to govern the religiously and morally pluralistic societies of today. That is, contemporary Muslim should avoid invading the moral space of other communities in as much as they would dread the imposition of alien moral or legal rules in their moral space.

\section{Conclusion}

To conclude, it can be said that it is wrong to pick examples and incidents occurring in some Muslim countries to typify the character of Sharia. Islamic teachings and values are universal without any discrimination and biases of caste, creed, colour and religion.

1 "Those who believed, and migrated, and fought for the faith, with their property and their persons, in the cause of God, as well as those who gave (them) asylum and aid - these are (all) friends and protectors, one of another. As to those who believed but chose not to migrate, you owe no duty of protection to them until they migrate; but if they seek your aid in religion, it is your duty to help them, except against a people with whom you have a treaty of mutual alliance. And (remember) God sees all that you do. The unbelievers are protectors, one of another: unless you do this (protect each other), there would be oppression and commotion on earth, and great mischief." (chapter 8: verse 72). 
Our examination of the Qur'anic discourse reveals to us the significance it places on human rights. While the Qur'an urges people to adopt high moral standards and observe other people's rights, it makes it quite clear that people are ultimately accountable to their creator for their moral failings and responsibility shortcomings.

It is to be made clear that Islam tries to achieve the above mentioned human rights and many others not only by providing certain legal safeguards but also through inviting mankind to transcend the lower level of animal life to be able to go beyond the mere ties fostered by the kinship of blood, racial superiority, linguistic arrogance, and economic privileges. It invites mankind to move on to a plane of existence where, by reason of his inner excellence, man can realize the ideal of the Brotherhood of man.

Received: April 5 $5^{\text {th }}, 2013$

Accepted: April 25 $5^{\text {th }}, 2013$

\section{References:}

The Holy Qur'an.

Afshari, Reza (1994), "An essay on Islamic Cultural Relativism in the Discourse of Human Rights", in Human Rights Quarterly 16 (2): 235-276.

Asad, Muhammad (1980), The Message of the Qur'an, translation, Gibraltar, Dar al-Andalus.

Fyzee, Asaf A. A. (1978), A Modern Approach to Islam, Lahore, Universal Books. Al-Ghazzali, Abu Hamid (1993), Fada'ih al-Batiniyyah, Jordan, Amman, Dar alBashir.

Hathout, M., Jamil, U., Hathout, G. and Ali N. (2006), In Pursuit of Justice: The Jurisprudence of Human Rights in Islam, Los Angeles, Muslim Public Affairs Council (MPAC).

Ibn Hisham (1955), al-Sirah al-Nabawiah, Cairo, Mustafa Halabi Press.

Ibn Nujaym, Ibrahim (1988), al-Asbah was al-Naza'ir, Damascus, Dar al-Fikr.

"Islam, Apostasy and PAS", at: http://www.sistersinislam.org.my/news. php?item.302.27 (01.04.2013).

Kamali, Mohamad Hashim (1998), Freedom of Expression in Islam, Kuala Lampur, Ilmiah Publishers.

Mayer, Ann Elizabeth (1995), Islam and Human Right: Tradition and Politics, $2^{\text {nd }}$ edition, Boulder, Colorado, Westview Press.

Parwez, Ghulam Ahmad (1977), Tabweeb-ul-Qur'an, Volume 1, Lahore, Idara Tulu'-e Islam.

Parwez, Ghulam Ahmad (1981), "Bunyadi Huquq-e Insaniyat”, in Tolu'-e-Islam 46: 34-35. 
Parwez, Ghulam Ahmad (1986), A Challenge to Religion, Lahore, Idara Tolu'-e-Islam.

Rizvi, Sayyid Muhammad, “Apostasy (Irtidad) in Islam”, at: http://www.al-islam. org/short/apostasy (01.04.2013).

Shanavas, T. O, "Apostasy in Islam Through the Eyes of a Former Apostate", Toledo Muslims, at: http://www.toledomuslims.com (01.04.2013).

Al-Shatibi, Abu Ishaq (1994), al-Muwafaqat, Beirut, Lebanon, Dar al-Mảrifah.

Sheikh Abdur Rahman (1986), Punishment of apostasy in Islam, Chicago, Kazi Publications.

Sulami, 'Izz al-Din 'Abd al-'Aziz ibn 'Abd al-Salam (1968), Qawa'id al-Ahkam (The Basis of Rules), Beirut, Arab World Publishing House.

Tahir-ul-Qadri Muhammad, "Islamic Concept of Human Rights", at: http:// www.al-islam.org (01.04.2013).

United Nations, "What are Human Rights?", at: http://www.ohchr.org/en/issues/ Pages/WhatareHumanRights.aspx (01.04.2013).

Yusuf Ali, Abdullah (1989), The Holy Quran (Translation), Brentwood, Maryland, Amana Corporation. 